\title{
多媒体在初中历史课堂教学中的运用
}

\author{
盘洪琼 \\ 贵州省六盘水市钟山区大湾镇幸福学校 \\ DOI:10.32629/jief.v2i5.1463
}

[摘 要] 多媒体教学是指在教学过程中, 根据教学目标和教学对象的特点, 通过教学设计, 以多种媒体信息作用于学生, 形成合理的教学过 程结构, 达到最优化的教学效果。在初中历史课堂教学中利用多媒体, 可以提高学生学习兴趣, 突出教学重点难点, 培养学生家国情怀, 增 长学生知识见识。

[关键词] 多媒体; 初中历史; 课堂教学

中图分类号: G633.51 文献标识码：A

历史课程是人文社会学科的一门基础课程, 具有思想性、基础性、人 文性和综合性的特点。在历史学科的教学中, 教师要引导学生通过学习, 初步学会从历史的角度观察和思考社会与人生, 从历史中汲取智慧, 逐步 树立正确的世界观、人生观和价值观，提高综合素质，得到全面发展。

然而, 历史学科的教学在初中阶段的地位却十分滥筴, 历史学科的 教学现实与历史学科的课程性质相去甚远。传统的照本宣科、填鸭式教 学广泛存在于初中历史课堂上, 课堂教学缺乏趣味性、启发性, 低效甚 至无效。在历史课堂教学中运用好多媒体是保障教学效果的有效途径。

多媒体教学是指在教学过程中, 根据教学目标和教学对象的特点, 通过教学设计, 合理选择和运用现代教学媒体, 并与传统教学手段有机 组合, 共同参与教学全过程, 以多种媒体信息作用于学生, 形成合理的 教学过程结构, 达到最优化的教学效果。

1 利用多媒体, 提高学生学习兴趣

历史是记载和解释一系列人类活动进程的历史事件的一门学科, 初 中历史统编教材坚持以唯物史观为指导, 按照历史时序, 展现中外历史 在政治、经济和文化等方面发展的基本进程。学生通过学习, 不仅要掌 握基本的历史史实, 而且要形成正确的历史认识, 凸显历史学科的育人 功能。但这些史料、史实、史观与现在的初中生的生活相距甚远, 学生 学习理解起来有一定的难度。

多媒体技术将历史转化为声音、文字、图像、动画、视频等多种形式呈 现在学生面前, 动静结合的画面和开放性的启发诱导, 使枯燥的历史概念、 历史材料变得直观化、具体化, 可以产生如见其人、如闻其声、身临其境的 感觉, 使学生在学习过程中的注意力、情感、兴趣等心理因素保持良好状态, 符合青少年学生的心理和认识特点, 有效地激发学生学习的兴趣。

如在教学《中华人民共和国成立》时, “开国大典”一目是该课的重 点。教材运用四段文字和三张图片记叙了开国大典的盛况及意义。文字描 写数字详实、自然生动, 但那只是文字和图片, 读起来总让人觉得意犹未 尽。此时, 利用多媒体播放 “开国大典” 盛况的视频, 可以让学生身临其 境地体会当时的礼炮齐鸣、万众欢滕的盛大场面，体会 “中国人民从此站 起来” 的欢欣鼓舞, 回顾中国百年来所受的耻辱, 作为中国人的自豪感和 民族㭉誉感油然而生。这样的教学, 激发了学生的学习兴趣, 点燃了学生 的学习热情, 引起了学生的思维碰撞和情感共鸣, 对于 “开国大典时为什 么要用 54 门礼炮齐鸣 28 响” 等问题的理解就会得心应手、顺理成章。

\section{2 利用多媒体，突出教学重点难点}

初中历史教材涉及中华优秀传统文化教育、革命传统教育、民族团 结教育、国家主权和海洋意识教育以及国际理解教育五大方面, 分时期、 分阶段从历史发展演进的角度使学生认识社会主义核心价值观的历史渊 源及现实意义, 每课的内容都是以节段式、非连续性的形式呈现, 学生 必须掌握的基础知识与基本技能繁多。每课都有学生不易理解的知识, 不易掌握的技能技巧。

历史是人类过去的实践活动, 在现实生活中不可能重演。学生对历 史的学习只能通过教材中的文字和图片来理解掌握。抽象、复杂的历史 事件、历史人物、历史现象和历史线索，有的因年代久远或地域空间概 念强, 学生感到陌生 (特别是地理位置), 教师也难以用传统教学方法和 媒质具体形象地加以描绘。将多媒体技术运用到课堂教学过程中，可以 提供形象化的教学信息, 变无声为有声, 变抽象为具体, 能以声音、图 像、视频等多种方式向学生提供学习材料, 屏幕显示的内容可以随意重 复和迅速更换, 表现事物的动态变化, 使某些抽象、难以表现的教学过 程得以实现, 从而有效调动学生的多种感官共同作用, 强化感知, 帮助 其建立起地域空间想象能力, 突破教学中的重难点。

东汉后期，外戚宦官交替专权，使得朝政腐败不堪，社会混乱，人 民遭殊, 导致了“黄巾起义” 的发生。“黄巾起义” 是东汉走向衰亡的转 折点, 是《东汉的兴衰》一课教学的重难点。在教学过程中, 教师播放 有关 “黄巾起义” 的视频, 引导学生了解黄巾起义的原因、领导人、发 生的时间、口号、结果、影响, 使学生明确黄巾起义沉重打击了东汉的 统治, 瓦解了东汉的政权, 以此引导学生进行历史思维能力的拓展, 培养

\section{学生透过历史现象认识事物本质的能力。}

3 利用多媒体, 培养学生家国情怀

家国情怀是历史学科五大核心素养之一, 是学习和探究历史应具有的 人文追求和价值关怀。在历史教学中培养学生的家国情怀, 就是要引导学 生通过学习和认知, 形成正确的价值取向, 培养学生形成对祖国文化的认 同感和正确的国家观, 确立积极进取的人生态度, 树立正确的 “三观”。 历史学科的学科特质决定了历史教育是培养学生家国情怀的主要方式。

历史教学过程中, 说教式的家国情怀教育往往不能引起学生的兴趣, 达不到培养学生家国情怀的目的。教师可根据教学实际情况, 借助多媒 体技术，播放有关能反映家国情怀的历史图片、视频、歌曲等，使抽象 难懂的教育直观而形象, 使课堂教学活动变得活泼生动, 从根本上改变 传统单调的教学模式, 从而激发学生的学习兴趣, 培养学生正确的情感 态度价值观，增强家国情怀教育的感染力。

如在教学《甲午中日战争与瓜分中国狂潮》时, 教师利用多媒体播 放电影《甲午风云》中黄海大战的片段，真实再现邓世昌等爱国将领英 勇抗敌的情景。视频让学生切身感受邓世昌等广大爱国官兵在这场战争 中所显现出来的顽强精神和爱国情感。学生怀着沉重的心情看完视频后, 反抗侵略、忧国忧民、富国强国的情感油然而生。在教学《抗日战争的 胜利》时, 利用播放 “胜利日” 天安门阅兵图片的形式导入新课, 引导 学生一起走进 70 年前那个烽火连天的抗争岁月, 感受抗日战争的胜利给 中国人民带来的无限感慨和激动。可以说, 学生身临其境的感触胜过教 师的千言万语的情感说教。

\section{4 利用多媒体, 增长学生知识见识}

2018 年 9 月 20 日, 在全国教育大会上, 习近平总书记指出: 要在增 长知识见识上下功夫, 教育引导学生珍惜学习时光, 心无旁坆求知问学, 增长见识，丰富学识，沿着求真理、悟道理、明事理的方向前进。历史课 堂教学作为历史教学的立足点和主阵地, 必须发挥历史学科的教育功能, 以培养和提高学生的历史素养为宗旨, 培养学生正确的史观; 以普及历史 常识为基础, 使学生掌握中外历史的基本知识, 初步具备学习历史的基本 方法和基本技能, 帮助学生增长知识见识, 促进学生的全面发展。

作为唯一留存下来的四大文明古国之一的中国, 我国历史悠久、文 化灿烂，炎黄子孙以自己的辛勤劳动、创新智慧和艰苦斗争，在祖国大 地上创造出灿烂辉煌的物质文明和精神文明, 留下了可歌可泣的历史篇 章。璀骤的文明、广表的土地, 都在历代文化的传承中得到了继承和发 展, 至今历久弥新。

中华文明显现出异彩纷呈的华章, 一个个惊心动魄的历史故事, 项项领先世界的科技发明，一个个载入史册的历史人物，一件件流传天 下的艺术珍品都因多媒体在历史课堂教学中的运用而显得熠熠生辉。学 生的知识见识在学习历史的过程中得以增长, 人类优秀的历史文化陶冶 了学生的心灵, 他们从历史中汲取智慧, 正确理解人与社会、人与自然 的关系, 逐步形成了正确的价值取向和积极向上的人生态度。

在初中历史教学中运用多媒体技术创设情境, 可将抽象内容具体形 象化, 微观事物宏观化, 复杂事物简约化, 从多方位刺激学生的感官, 有利于激发学生学习的兴趣, 陶治学生的情操, 培养学生的思维能力, 强化学生的记忆, 是提高课堂效率, 促进学生增长知识见识, 促进学生 整体素质提高的有效途径。

\section{[参考文献]}

[1]何文奇.如何让信息化技术走进初中历史课堂教学 [J].新课 程,2020(37):6

[2]杨国民.初中历史教育教学中高效课堂的构建路径研究[J].新课 程,2020(37):173.

[3] 李金花.试论初中历史教学中德育工作的渗透策略[J].文理导航 (上旬),2020(09):53。

作者简介：盘洪琼（1972-)，女，贵州省六盘水市钟山区大湾 镇幸福学校教师，高级教师（中)。 